\title{
The Combat Fitness Test - Its Victorian Origins
}

Major J DC Bennett

BSc, FRCS, DCH, DHMSA, RAMC, Senior Specialist in Otolaryngology

British Military Hospital, Rinteln, BFPO 29

SUMMARY: The Royal Army Medical Corps and its predecessors have always had an interest in the selection and $\stackrel{\vec{\rho}}{\rightarrow}$ training methods of the Army, especially when physiological principles are in question. Surgeon Major Davy appears $\bar{C}$ to have suggested an early combat fitness test as a better method of assessing the suitability of recruits.

\section{Introduction}

Surgeon Major Francis Arthur Davy MD (1846-1919) was a relatively obscure medical officer who was commissioned in 1868. During his service he saw two years in Afghanistan and finally retired as a major in 1888 to work on the retired list in Sheffield. The designation of his departmental rank was altered to Surgeon Lieutenant Colonel 1 October 1888 under a London Gazette notification of 17 October 1893 and he became a Lieutenant Colonel on 9 August $1898^{1}$. This rather undistinguished career is misleading however. He was a keen physiologist and astute observer, writing three articles on current training methods. Only the first was published ${ }^{2}$. The following two were in Davy's words "submitted for publication in subsequent reports, but for want of space, have not been published". This is a shame for they contain an idea for a physical fitness test which the current Combat Fitness Test closely follows. In November 1923 Sir Ronald Ross wrote to General Sir William Leishman KCMG FRS that he had what was almost certainly the only remaining copy of this pamphlet and that he did not know what had happened to Davy but that "he certainly did some good work". This copy is now in the History of Medicine collection of the Wellcome Foundation. It was printed by F J Cattermole, 20/21 Artillery Place, Woolwich, 1883.

Davy draws attention to the fact that in the recruit's training he is called upon to obey orders which although "designed to benefit himself and the State, are founded in error and have the opposite effect - they defeat the very ends they have in view". It is not too hard to see why such an article was refused publication, nevertheless the reader is left with the impression that Davy had made a thorough study of the consequences of too slavish adherence to a rigorous drill book Section 1 Part 1 of which gives directions regarding the "position of the soldier", the directions being that the hips were to be drawn back, the breast advanced but without constraint, the body straight and inclining forward, so that the weight of it may bear principally on the forepart of the feet. The knees were to be straight and the heels together. Davy comments that "the part to which I wish to call attention is that which directs that the weight of the body may principally bear on the fore part of the feet". He observed how the recruit effected a compromise between what was required and what was anatomically more sound: "He soon finds that to obey it implicitly means great, because continuous, strain on the muscles $\mathbb{\perp}$ of the calf. He would like much to ease them by letting the 0 calcaneal end of the longitudinal arches of the foot support its portion i.e. the greater portion, of the weight: but to do this would be to cease to incline the body as directed, and to make the heel bear the principal part of the weight; which common sense, backed by Anatomy, says it ought to bear; but which the drill sergeant, backed by the drill book, says it ought not. In order to relieve this paradox the recruit allows the pelvis to go a little forward: which movement - although the weight is still on "the forepart of the feet" - has the effect of making a very slight arch of the whole body, and so lessens the expenditure of $\vec{N}$ muscular power required to maintain the attitude. Thap the men resort to this expedient of advancing the pelvis $\vec{B}$ well known to drill sergeants, who combat it by blows oक

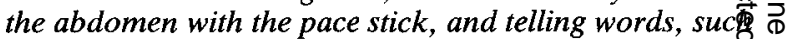
as they deem descriptive of the appearance produced $b_{\dot{\phi}} \overrightarrow{0}$ it; and calculated to awaken in any nice-minded recrub the determination never to resort to it again."

Davy considered this order for the disposition of the weight of the body to be wrong, from a mechanical well as from a physiological point of view, because, in s $\overrightarrow{0}$ far as it is obeyed, it does away with the advantages of the arches of the foot, and in time actually flattens them. In this he was not alone, as reported in the editorial of the Lancet: "It does not need a knowledge of Anatomy to convince the shallowest thinkers of the sex which worships the idol of fashion, that the foot is forced into a wholly unnatural position, and distorted, by the heel being raised, and the body made to rest on the ball of the toes $^{3}$.

The aggrieved writer goes on to state "It should be unnecessary to explain that this disturbance of the foundation throws the whole superstructure out of gear, and deranges every mechanical function" 3 .

Davy was also concerned that although the recruit was not directed by the drill book to raise his heels off the ground in assuming the "position of the soldier", he noticed that in some regiments the drill sergeant convinced himself that the heels were actually raised by seeing whether he could pass a piece of cardboard or paper under them.

Disquiet was not confined to the medical profession, and there was general public concern about recruits to 0 the Army, especially their youth, to such extent that $\mathrm{Mr} \omega$ Hardy delivered a speech in the House of Commons in 
March 1878: "I have had a table prepared, first of all as regards men under one year's service but dismissed drill. These were taken from 21 different corps and I find there were 1452 men whose average weight was $10 \mathrm{st} 7 \mathrm{lb}$, average age 21 years and one month and average chest measurement 35 inches. Though some of these are boysnot men-you have not in these regiments a bad class of recruits (quoted from newspaper report). The Commander in Chief went down this morning to inspect the men, and he has written to me to express the great satisfaction which he felt at what he saw. He was very much struck with the men who have passed the drill, and he is quite sure we have a good class of recruits." Davy makes the point that it is impossible to judge a man's powers of endurance by simply looking at him and makes the suggestion: "To test the matter, let him - after a march, in marching order, of 10 to 15 miles - be told to throw off his pack and double four hundred yards up an incline, rifle in hand, and carrying 25 to 30 rounds of ammunition; and commence firing at once at a target 300 yards distant. Suppose we make new recuits practice such an exercise as the above (leaving out the ball firing which they have not yet been taught) and beginning with one of about half the difficulty. Let this be done every second $a$ third day, and on the intervening days let them be taught military manoeuvres and movements, instead of sending 0 them to the drill sergeant."

The aphorism that: "There are few things new, only $\stackrel{\text { ? }}{=}$ forgotten things rediscovered" seems to be well demonstrated here. Around the centenary of his retirement perhaps we ought to reflect what progress has $\underline{\sigma}$ been made since then, and also how many things $\frac{\bar{m}}{}$ (re)discovered had their origins in the Medical Services $\mathbb{D}$ of the British Army.

\section{REFERENCES}

1. JoHnston W. Roll of Commissioned Officers In The Medical Service of the British Army. Aberdeen: University Press 1917.

2. Davy F A. 1876; The Army Medical Report.

3. Lancet 1876 ; Editorial 9 March. 